\title{
Wpływ cech przedsiębiorcy na kształtowanie dynamicznych zdolności przedsiębiorstw w dziatalności międzynarodowej
}

\author{
Dr hab. Kamila Malewska iD \\ Uniwersytet Ekonomiczny w Poznaniu \\ Katedra Teorii Organizacji i Zarządzania
}

Dr hab. Milena Ratajczak-Mrozek, prof. UEP

Uniwersytet Ekonomiczny w Poznaniu Katedra Marketingu Międzynarodowego

Dr hab. Maja Sajdak iD

Uniwersytet Ekonomiczny w Poznaniu Katedra Zarządzania Strategicznego

\section{Wprowadzenie}

Coraz więcej przedsiębiorstw podejmuje się zmian strategicznych, decydując się na prowadzenie działalności międzynarodowej związanej z obsługą zagranicznych klientów, współpracą międzynarodową lub wyłącznie pozyskiwaniem zagranicznych surowców. Jest to możliwe między innymi dzięki dynamicznie rozwijającym się zdolnościom, które stanowią odpowiedź na rosnącą dynamikę otoczenia. Egzemplifikują one możliwość dokonywania rekonfiguracji oraz zmiany w bazie zasobów i kompetencji w celu adaptowania się do warunków wysoce zmiennego otoczenia ${ }^{1}$. Jak podkreślają między innymi Mitręga, Henneberg i Forkmann, koncepcja dynamicznych zdolności pozostaje tematem mało eksplorowanym w literaturze, a mającym silny wpływ na całą dziedzinę zarządzania strategicznego

1 M. Vijaya Sunder, L.S. Ganesh, R.R Marathe, Dynamic capabilities. A morphological analysis framework and agenda for future research, „European Business Review” 2018, vol. 31, no. 1, s. 25-63. 
i dziedziny pokrewne². Jednocześnie Cyfert i Krzakiewicz przekonują, że dynamiczne zdolności są podejściem teoretycznym niezwykle istotnym z punktu widzenia wyjaśnienia fenomenu konkurowania przedsiębiorstw ${ }^{3}$.

Należy zauważyć, że zależność między cechami osób zarządzających (jednostek, przedsiębiorców lub menedżerów najwyższego szczebla) a formułowaniem dynamicznych zdolności organizacji (przedsiębiorstw) nadal nie została jednoznacznie sprecyzowana i wymaga dalszych analiz ${ }^{4}$. Lukę badawczą dostrzec można w identyfikacji bardziej szczegółowych zależności między zdolnościami jednostki a zdolnościami organizacyjnymi (przedsiębiorstwa) i vice versa. W literaturze postuluje się, że cechy osobowości osób zarządzających (tak zwany profil przedsiębiorcy) mają wspływ na skuteczność podejmowania działań strategicznych ${ }^{5}$. Brakuje jednak badań łączących perspektywę cech przedsiębiorcy z dynamicznymi zdolnościami samych przedsiębiorstw. Jak wskazują Helfat i Peteraf, problem ten stanowi ważny obszar przyszłych badań6. Ponadto, choć w literaturze podkreśla się znaczenie dynamicznych zdolności dla umiędzynarodowienia przedsiębiorstw ${ }^{7}$, brakuje kompleksowych badań łączących perspektywę cech osób zarządzających, dynamicznych zdolności samych przedsiębiorstw oraz wpływu wskazanych zależności na skuteczność działań strategicznych na rynkach międzynarodowych. Jest to o tyle ważne, że działalność międzynarodowa przedsiębiorstw charakteryzuje się większą zmiennością i różnorodnością w porównaniu z działalnością wyłącznie krajową ${ }^{8}$. Wynika to między innymi z dystansu geograficznego, różnic kulturowych czy legislacyjnych, które skutkują wyższymi kosztami transportu, potrzebą koordynacji działań oraz adaptacją do odmiennych wymogów prawnych czy technologicznych. $Z$ tego powodu uważa się, że działalność międzynarodowa

2 M. Mitręga, S. C. Henneberg, S. Forkmann, Capabilities in business relationships and networks: An introduction to the special issue, „Industrial Marketing Management” 2018, vol. 74, s. 1-3.

3 S. Cyfert, K. Krzakiewicz, The role of opportunity sensing and learning processes in shaping dynamic capabilities in Polish enterprises, „Management” 2016, vol. 20, no. 1, s. 277-291.

4 J.P. Eggers, S. Kaplan, Cognition and capabilities: a multi-level perspective, „Academy of Management Annals" 2013, vol. 7, no. 1, s. 293-338.

5 M. Simon, S. M. Houghton, K. Aquino, Cognitive biases, Risk Perception, and venture formation: How individuals decide to start companies, „Journal of Business Venturing” 2000, vol. 15, no. 2, s. 113-134.

6 C.E. Helfat, M.A. Peteraf, Managerial cognitive capabilities and the microfoundations of dynamic capabilities, „Strategic Management Journal” 2015, vol. 36, no. 6, s. 961-979.

7 C. Prange, S. Verdier, Dynamic capabilities, internationalization processes and performance, „Journal of World Business” 2011, vol. 46, no. 1, s. 126-133.

8 S. Beugelsdijk, Liability of Foreignness and Location-Specific Advantages: Time, Space and Relative Advantage, „Advances in International Management” 2015, vol. 24, s. 181-210; O. Shenkar, Y. Luo, International Business, Wiley, Chichester 2004, s. 10-11. 
w porównaniu z krajową charakteryzuje się większym ryzykiem i wymaga specjalnych kompetencji osób zarządzających ${ }^{9}$.

Celem rozdziału jest zidentyfikowanie wpływu cech przedsiębiorcy (jednostki) na kształtowanie dynamicznych zdolności przedsiębiorstwa, umożliwiających skuteczność działań strategicznych na rynkach międzynarodowych. W opracowaniu skuteczność działań na rynkach międzynarodowych definiowana jest jako realizacja celów związanych z ekspansją na nowe rynki zagraniczne i z dalszym prowadzeniem działalności na tych rynkach. Fundament teoretyczny niniejszego rozdziału stanowi podejście behawioralne ${ }^{10}$, eksponujące rolę osób zarządzających, podejmowanych przez nie wyborów, które stanowią de facto o wynikach przedsiębiorstwa. W opracowaniu, na podstawie analizy literatury przedmiotu, zaproponowano model koncepcyjny zakładający istnienie zależności między cechami przedsiębiorcy, dynamicznymi zdolnościami jednostki, dynamicznymi zdolnościami całego przedsiębiorstwa oraz skutecznością działań strategicznych na rynkach międzynarodowych.

Rozpoznanie powyższego celu umożliwi menedżerom zrozumienie kluczowych cech leżących u podstaw rozwoju dynamicznych zdolności. Ponadto opracowanie modelu koncepcyjnego przyczyni się do wyjaśnienia, w jaki sposób odmienny poziom dynamicznych zdolności różnicuje efektywność w antycypowaniu, interpretowaniu oraz reagowaniu na zmiany w działalności międzynarodowej.

Rozdział składa się z trzech części poprzedzonych wprowadzeniem oraz podsumowanych zakończeniem. Część pierwsza ma charakter teoretyczny i koncentruje się na dynamicznych zdolnościach przedsiębiorstw i ich roli w działalności międzynarodowej. W części drugiej przedstawiono znaczenie cech przedsiębiorcy, ze szczególnym uwzględnieniem jego zdolności kognitywnych i ich wpływu na tworzenie dynamicznych zdolności jednostki. W trzeciej części opracowania zaproponowano model koncepcyjny obrazujący zależności między cechami przedsiębiorcy a dynamicznymi zdolnościami przedsiębiorstw. W podsumowaniu zwrócono uwagę na możliwości aplikacji modelu oraz kierunki przyszłych badań.

9 M. Gorynia, Strategie zagranicznej ekspansji przedsiębiorstw, Polskie Wydawnictwo Ekonomiczne, Warszawa 2007.

10 D.C. Hambrick, P.A. Mason, Upper echelons: The organization as a reflection of its top managers, „Academy Management Review” 1984, vol. 9, s. 195-206. 


\section{Istota dynamicznych zdolności przedsiębiorstw w dziatalności międzynarodowej}

Dynamiczne zdolności przedsiębiorstw należy rozumieć jako zdolności złożone z cennych i trudnych do replikacji organizacyjnych rutyn i procesów, umożliwiających podejmowanie zmian poprzez wyczuwanie szans i zagrożeń oraz rekonfigurowanie zasobów w celu wykorzystania tych szans ${ }^{11}$. Dynamiczne zdolności odnoszą się „do wzorców zachowań członków organizacji, które koncentrują się na modyfikacji istniejących zasobów i kompetencji organizacji w taki sposób, że organizacja staje się lepiej dostosowana do warunków otoczenia"12.

Przedsiębiorstwa prowadzące działalność na rynkach międzynarodowych zazwyczaj muszą sobie radzić z większą różnorodnością i zmiennością otoczenia oraz większym ryzykiem ${ }^{13}$. W związku z tym można założyć, że w przypadku aktywności przedsiębiorstwa na rynkach międzynarodowych większe znaczenie dla jego skuteczności, rozumianej jako realizacja celów, mają dynamiczne zdolności. Im bardziej dynamiczny rynek, tym silniejsza potrzeba rozwoju dynamicznych zdolności. Większość prac naukowych podejmujących tematykę dynamicznych zdolności skupia się na zmianie, kreowaniu i rozwijaniu oraz rekonfigurowaniu zasobów w odpowiedzi na zmiany w otoczeniu ${ }^{14}$. W literaturze wskazuje się przykłady międzynarodowych firm, takich jak Tata z Indii, Alibaba z Chin czy Embraer z Brazylii, które dzięki kluczowej roli dynamicznych zdolności wprowadziły skutecznie innowacje i odniosły sukcesy na arenie międzynarodowej15. Rosnące dowody na znaczenie dynamicznych zdolności dla skuteczności działań przedsiębiorstw w perspektywie międzynarodowej ${ }^{16}$, szczególnie w powiązaniu dynamicznych zdolności z wprowadzaniem innowacji, zachęcają do dalszych badań w poszukiwaniu innych zależności gwarantujących sukces.

11 D.J. Teece, Explicating dynamic capabilities: The nature and microfoundations of (sustainable) enterprise performance, „Strategic Management Journal” 2007, vol. 28, no. 13, s. 1319-1350.

12 M. Mitręga, Dynamiczne zdolności - wzloty i upadki paradygmatu strategii, „Studia i Prace Wydziału Nauk Ekonomicznych i Zarządzania Uniwersytetu Szczecińskiego" 2017, nr 48/2, s. 59.

13 S. Beugelsdijk, Liability of Foreignness...; O. Shenkar, Y. Luo, International...

14 M. Najda-Janoszka, Dynamic capability-based approach to value appropriation, Jagiellonian University Press, Cracow 2016, s. 72.

15 I. Gölgeci, S. Assadinia, O. Kuivalainen, J. Larimo, Emerging-market firms' dynamic capabilities and international performance: The moderating role of institutional development and distance, „International Business Review” 2019, vol. 28, no. 6, s. 1-13.

16 O. Schilke, S. Hu, C.E. Helfat, Quo vadis, dynamic capabilities? A content-analytic review of the current state of knowledge and recommendation for future research, „Academy of Management Annals" 2018, vol. 12, no. 1, s. 390-439. 
Dynamiczne zdolności oznaczają nieustrukturyzowane, elastyczne sposoby działania, umożliwiające skuteczne formy aktywności strategicznej w niepewnym otoczeniu międzynarodowym. Jedną z podstawowych cech dynamicznych zdolności jest elastyczność działań umożliwiająca aplikację określonych rozwiązań w ramach różnych obszarów funkcjonowania (domen). Oznacza to, że przedsiębiorstwa mają zdolności transformacyjne, umożliwiające im przeprowadzanie zmian o charakterze strategicznym i gwarantujące skuteczną adaptację do zmieniających się warunków otoczenia. Wykorzystanie dynamicznych zdolności może zatem prowadzić do zmiany strategii organizacji jako całości ${ }^{17}$.

Zdolności dynamiczne przedsiębiorstw reprezentują zdolności wyższego rzędu, które wpływają na szybkość, z jaką przedsiębiorstwo jest w stanie skutecznie działać i reagować na zmiany otoczenia ${ }^{18}$. Według podziału zaproponowanego przez Teece’a dynamiczne zdolności przedsiębiorstw obejmują trzy główne kategorie ${ }^{19}$ : zdolność wyczuwania szans (okazji) i zagrożeń, zdolność wykorzystywania tych okazji oraz zdolność rekonfiguracji zasobów, kompetencji i procesów.

Zdolność wyczuwania (sensing capability) ma na celu rozpoznawanie zmian i monitorowanie szans oraz zagrożeń zarówno wewnątrz przedsiębiorstwa, jak i w jego otoczeniu. Dynamika otoczenia (intensywność, złożoność, burzliwość) wymaga uwzględnienia charakteru zmian, które w nim zachodzą, dzięki którym okazje mogą się pojawiać, ale także dzięki zmianom (np. w strukturze konkurencji, panujących trendów, gustów klientów) przedsiębiorstwo może je kreować. Zdolność wyczuwania odnosi się do umiejętności skanowania otoczenia, szacowania i filtrowania zmian, monitorowania trendów, uczenia, jak również interpretowania otoczenia i wychwytywania z niego okazji oraz zagrożeń. Te wszystkie zdolności są niezwykle istotne w internacjonalizacji przedsiębiorstw. Wykorzystując zdolność wyczuwania, przedsiębiorstwa są w stanie przede wszystkim zidentyfikować okazje sprzyjające rozwojowi działalności międzynarodowej20. Okazje wpływają na to, kiedy i jak rozpoczyna się proces internacjonalizacji, często to właśnie zidentyfikowana okazja stanowi podstawę decyzji o podjęciu współpracy z zagranicznym klientem, dostawcą czy partnerem biznesowym ${ }^{21}$. Zdolność

17 M. Sajdak, Zwinność strategiczna przedsiębiorstw, Wydawnictwo Uniwersytetu Ekonomicznego w Poznaniu, Poznań 2019, s. 73.

18 M. Easterby-Smith, M.A. Lyles, M.A. Petaraf, Dynamic Capabilities: Current Debates and Future Directions, „British Journal of Management” 2009, vol. 20, s. S1-S8; S.G. Winter, Understanding dynamic capabilities, „Strategic Management Journal” 2003, vol. 24, s. 991-995.

19 D.J. Teece, Explicating dynamic capabilities...

20 M. Mitręga i wsp., Networking capability in business relationship - concept and scale development, „Industrial Marketing Management” 2012, vol. 41, s. 739-751.

21 M. Ratajczak-Mrozek, Network Embeddedness. Examining the Effect on Business Performance and Internationalization, Palgrave Macmillan, Cham 2017, s. 317-322. 
do identyfikowania okazji w procesie internacjonalizacji koncentruje się w dużej mierze w obszarze badań nad międzynarodową przedsiębiorczością ${ }^{22}$, definiowaną jako „proces twórczego odkrywania i wykorzystywania okazji, które leżą poza rynkami krajowymi przedsiębiorstwa, w dążeniu do przewagi konkurencyjnej"23. Ponadto dzięki zdolności wyczuwania przedsiębiorstwa prowadzące działalność międzynarodową podejmują inwestycje w działalność badawczą, poszukują skutecznych technik identyfikowania zmieniających się potrzeb klientów, informacji o dostawcach i konkurentach, rozwijają możliwości technologiczne ${ }^{24}$.

Zdolność wykorzystywania okazji (seizing capability) wiąże się bezpośrednio z umiejętnością uczenia się, odzwierciedloną poprzez dynamiczną zdolność do efektywnego wykorzystania wiedzy wewnątrz przedsiębiorstwa, zdobywania wiedzy $z$ otoczenia, asymilowania wewnętrznej i zewnętrznej wiedzy przez dzielenie się nią, co jest warunkiem kluczowym dla zdolności tworzenia wie$\mathrm{dzy}^{25}$. Wiedza i proces uczenia się stanowią podstawę modeli internacjonalizacji ${ }^{26}$. Uczenie może poprawić efektywność zarządzania w perspektywie międzynarodowej poprzez właściwe wykorzystanie okazji pojawiających się w otoczeniu, sprzyjając dalszej ekspansji międzynarodowej ${ }^{27}$. Na potrzebę wykorzystania okazji w działalności międzynarodowej zwracają uwagę Vahlane i Johanson ${ }^{28}$, definiując okazję jako „najważniejszy element zasobu wiedzy, który napędza proces internacjonalizacji”" ${ }^{29}$. Decyzje o wykorzystaniu okazji w otoczeniu międzynarodowym poprzez inwestycje strategiczne wymagają uzasadnienia i zdolności rozwiązywania problemów w celu opracowania opcji inwestycyjnych i oceny ich

22 P. D. Ellis, Social ties and international entrepreneurship: Opportunities and constraints affecting firm internationalization, „Journal of International Business Studies” 2011, vol. 42, no. 1 , s. 99-127.

23 S.A. Zahra, G. George, International entrepreneurship: The current status of the field and future research agenda, [w:] M.A. Hitt, R.D. Ireland, M. Camp, D. Sexton (red.), Strategic Entrepreneurship: Creating a New Mindset, Wiley-Blackwell, Oxford 2002, s. 258.

24 L. Cao, Dynamic capabilities in a turbulent market environment: empirical evidence from international retailers in China, „Journal of Strategic Marketing” 2011, vol. 19, no. 5, s. 455-469.

25 M. Li, F. Gao, Why Nonaka highlights tacit knowledge: a critical review, „, Journal of Knowledge Management" 2003, vol. 7, no. 4, s. 6-14.

26 J.E. Vahlne, J. Johanson, From internationalization to evolution: The Uppsala model at 40 years, „Journal of International Business Studies” 2017, vol. 48, no. 9, s. 1087-1102.

27 Y. Li, H. Chen, Y. Liu, M.W. Peng, Managerial ties, organizational learning, and opportunity capture: a social capital perspective, „Asia Pacific Journal of Management” 2014, vol. 3, no. 1, S. 271-291.

28 J.E. Vahlne, J. Johanson, From internationalization...

29 J.E. Vahlne, J. Johanson, The Uppsala internationalization process model revisited: From liability of foreignness to liability of outsidership, „Journal of International Business Studies” 2009, vol. 40, no. 9, s. 1424. 
potencjału zysku. Zaprojektowanie skutecznego modelu biznesu, który umożliwi wykorzystanie okazji na rynkach międzynarodowych, wymaga dopasowania wielu elementów, z uwzględnieniem dopasowania strategicznego (strategic fit) oraz komplementarności działań ${ }^{30}$.

Zdolność rekonfiguracji (reconfiguring capability) odnosi się do tworzenia i integracji zasobów oraz zdolności wewnętrznych lub nabytych z zewnątrz przedsiębiorstwa. Jest to transformacja istniejących zasobów i zdolności, która przejawia się zmianą formy, kształtu lub wyglądu zasobów istniejących w przedsiębiorstwie oraz obejmuje przegrupowanie lub rekombinację istniejących zdolności. Organizacja zasobów odnosi się do selekcji, konfiguracji, łączenia i modyfikacji zasobów materialnych i niematerialnych ${ }^{31}$. Adaptacja do zmian pojawiających się w otoczeniu międzynarodowym i przede wszystkim umożliwienie samej ekspansji międzynarodowej wymaga wzmocnienia lub modyfikacji zasobów strategicznych poprzez innowacje i organizacyjne uczenie się 32 , jak również nabywanie nowych zasobów od partnerów zewnętrznych ${ }^{33}$. W literaturze zwraca się uwagę na rolę rekonfiguracji struktury przedsiębiorstwa oraz umiejętność dostosowania kultury organizacyjnej, które w procesie umiędzynarodowienia mogą stanowić kluczowe czynniki determinujące sukces działań strategicznych ${ }^{34}$. Szczególnie istotny jest ten aspekt w działalności międzynarodowej, gdzie różnice kulturowe często stanowią barierę mentalną ograniczającą zaufanie i współpracę. Zdolność rekonfiguracji, uwzględniająca proces transformacji posiadanych zasobów, oznacza działanie w czasie podlegające dynamice - intensywności, częstości i szybkości zmian. Ze względu na dynamikę międzynarodowego otoczenia przedsiębiorstwa muszą uwzględnić znacznie większą różnorodność uwarunkowań niż w przypadku działalności ograniczonej do rynku macierzystego.

Nie ma wątpliwości, że kluczowym i najcenniejszym zasobem przedsiębiorstwa są ludzie i ich zdolności, dzięki którym budowane są zdolności przedsiębiorstwa jako całości. Coraz częściej zwraca się uwagę na znaczenie jednostek (przedsiębiorcy, menedżera najwyższego szczebla) jako mikrofundamentów dynamicznych zdolności przedsiębiorstw ${ }^{35}$. Trzeba zauważyć, że pomimo iż Teece, proponując trzy główne kategorie dynamicznych zdolności, odnosi się do ich poziomu organizacyjnego, to jednak

30 C.E. Helfat, M.A. Peteraf, Managerial cognitive capabilities...

31 C.E. Helfat i wsp., Dynamic Capabilities: Understanding Strategic Chance in Organization, Blackwell Publishing, Malden 2007.

32 M. Zollo, S.G. Winter, Deliberate learning and the evolution of dynamic capabilities, „Organization Science" 2002, vol. 13, no. 3, s. 339-351.

33 C.E. Helfat, M.A. Peteraf, Managerial cognitive capabilities...

34 I. Gölgeci i wsp., Emerging-market...

35 C.H. Helfat, M.A. Peteraf, Managerial cognitive capabilities... 
podkreśla znaczenie osób zarządzających (zwłaszcza ich dynamicznych zdolności) jako podstawę tworzenia dynamicznych zdolności przedsiębiorstwa ${ }^{36}$. Adner i Helfat doszli do wniosku, że wybrani zarządzający mają tzw. dynamiczne zdolności jednostki, które umożliwiają budowanie, integrację, rekonfigurację oraz alokację zasobów i umiejętności organizacyjnych, co z kolei przekłada się na tworzenie dynamicznych zdolności przedsiębiorstwa ${ }^{37}$. Dlatego też można przyjąć, że podstawą kształtowania dynamicznych zdolności przedsiębiorstw może być wykorzystanie koncepcji dynamicznych zdolności jednostki, wskazującej na fakt, że zdolności nie odnoszą się jedynie do działań materialnych przedsiębiorstw, ale także do aktywności mentalnej osób zarządzających ${ }^{38}$. Oznacza to, że sugerowany w literaturze podział dynamicznych zdolności przedsiębiorstwa (wyczuwanie, wykorzystywanie, rekonfigurowanie) jest taki sam w przypadku podziału dynamicznych zdolności przedsiębiorcy, z różnicą poziomu analizy obu tych koncepcji.

\section{Cechy przedsiębiorcy w kontekście ksztattowania dynamicznych zdolności jednostki - znaczenie zdolności kognitywnych}

Przedsiębiorca pełni najistotniejsze funkcje $\mathrm{w}$ organizacji, wytycza podstawowe cele i podejmuje decyzje strategiczne oraz angażuje się w bieżącą działalność przedsiębiorstwa. W klasycznym ujęciu przedsiębiorca to człowiek będący zarówno założycielem przedsiębiorstwa, jak i osobą nim zarządzającą, ponoszącą całkowite ryzyko i odpowiedzialność finansową, związane z jego prowadzeniem. Wraz z kształtowaniem się coraz większych przedsiębiorstw nastąpiło zaburzenie jedności tych trzech funkcji, co oznacza, że ktoś inny jest założycielem firmy, ktoś inny nią zarządza i ktoś inny ponosi ryzyko finansowe ${ }^{39}$. W związku z powyższym na potrzeby analizy przyjęto założenie, zgodnie z którym niniejsze rozważania dotyczą przedsiębiorcy, ale w przypadku dużych przedsiębiorstw odnoszą się do menedżerów najwyższego szczebla (sytuacja, w której ma miejsce rozdzielenie osoby inicjatora przedsięwzięcia oraz osoby zarządzającej).

36 D.J. Teece, Explicating dynamic capabilities...

37 S.A. Adner, C.E. Helfat, Corporate effects and dynamic managerial capabilities, „Strategic Management Journal" 2003, vol. 24, no. 10, s. 1011-1025.

38 C.E. Helfat, M.A. Peteraf, Managerial cognitive capabilities...

39 K. Malewska, Entrepreneurial profile and the level of individual entrepreneurship, [w:] C. Costa, M. Au-Yong-Oliveira, M.P. Castro Amorim (red.), Proceedings of the 13th European Conference on Innovation and Entrepreneurship ECIE 2018, Academic Conferences and Publishing International Ltd, Reading 2018, s. 443-449. 
W literaturze przedmiotu nie ma zgodności co do definicji profilu przedsiębiorcy. Proponuje się różne ujęcia. Jedni autorzy traktują profil przedsiębiorcy jako jego kompetencje, obejmujące trzy podstawowe elementy: wiedzę, umiejętności i zdolności do efektywnego wykonania danej czynności ${ }^{40}$. Inni autorzy postulują, że jest to zespół motywów, cech, postaw, wartości, wiedzy, zdolności kognitywnych oraz innych charakterystyk, które wyróżniają jednostkę z punktu widzenia efektywności osiąganych wyników ${ }^{41}$. Spotkać się można także z podejściem, zgodnie z którym profil przedsiębiorcy obejmuje zachowania i działania przedsiębiorcy odnoszące się do czterech podstawowych cech: dążenia do rozwoju poprzez poszukiwanie okazji, tolerancji wieloznaczności, wiedzy eksperckiej oraz postrzegania ryzyka ${ }^{42}$. W literaturze postuluje się, że cechy osobowości przedsiębiorcy mają wpływ na skuteczność identyfikowania okazji i są jedną $\mathrm{z}$ podstawowych determinant powodzenia w prowadzeniu działalności międzynarodowej ${ }^{43}$.

W publikacjach autorzy zwracają uwagę na charakterystyczne cechy skutecznego przedsiębiorcy, które tworzą relatywnie spójny profil ${ }^{44}$. W tabeli 1 przedstawiono pożądane cechy współczesnego przedsiębiorcy, stanowiące odpowiedź na złożoność i dynamikę otoczenia. Wybór tych cech spośród wielu proponowanych w literaturze zdeterminowany był problemami, z którymi muszą radzić sobie współcześni przedsiębiorcy, wśród których wymienić można między innymi: konieczność pozyskania, przeanalizowania i dokonania syntezy wielu informacji, podejmowania decyzji pod presją czasu, rozwiązywania problemów jednostkowych, złożonych i nieustrukturyzowanych czy podejmowania decyzji w warunkach ryzyka i niepewności 45 .

40 J.S. Shippmann i wsp., The practice of competency modeling, „Personnel Psychology” 2000, vol. 53, s. 703-740.

41 L.M. Spencer, D.C. McClelland, C. Spencer, Competency Assessment Methods: History and State of the Art, Hay Mc-Ber Research Press, Boston 1994.

42 M. Gruber, I.C. MacMillan, Entrepreneurial behavior: A reconceptualization and extension based on identity theory, „Strategic Entrepreneurship Journal” 2017, vol. 11, no. 3, S. 271-286.

43 M.B. Oviatt, R.C. Shrader, P.P. McDougall, The internationalization of new ventures: A risk management model, [w:] M.A. Hitt, J.L.C. Cheng (red.), Theories of the Multinational Enterprise: Diversity. Complexity and Relevance, Emerald Group Publishing Limited, Amsterdam 2004, s. $165-185$.

44 T. Oleksyn, Przedsiębiorczość jako kategoria złożona. Jakją rozwijać?, „Problemy Zarządzania" 2012, t. 10, nr 1(36), s. 12; Z. Knecht, Przedsiębiorczość i przedsiębiorca, Wyższa Szkoła Oficerska Wojsk Lądowych im. Generała T. Kościuszki, Wrocław 2016, s. 149-152.

45 K. Malewska, Intuicja w podejmowaniu decyzji kierowniczych, Wydawnictwo Uniwersytetu Ekonomicznego w Poznaniu, Poznań 2018, s. 102-103. 
Tabela 1. Pożądane cechy współczesnego przedsiębiorcy

\begin{tabular}{|c|c|}
\hline $\begin{array}{l}\text { Pożądane cechy } \\
\text { współczesnego } \\
\text { przedsiębiorcy }\end{array}$ & Opis cechy \\
\hline $\begin{array}{l}\text { Pozyskiwanie } \\
\text { i przetwarzanie } \\
\text { informacji integrujące } \\
\text { podejście analityczne } \\
\text { i intuicyjne (percepcja, } \\
\text { poznanie społeczne, } \\
\text { wnioskowanie) }\end{array}$ & $\begin{array}{l}\text { O sukcesie przedsiębiorcy decyduje przede wszystkim sposób, } \\
\text { w jaki przyswaja informacje oraz przetwarza uzyskaną wiedzę. Jest } \\
\text { to uzależnione od mechanizmów poznawczych (m.in. percepcji, } \\
\text { poznania społecznego), którymi posługuje się dana jednostka. } \\
\text { Przedsiębiorca powinien umiejętnie tączyć podejście intuicyjne } \\
\text { i analityczne w procesie pozyskiwania i przetwarzania informacji. } \\
\text { Wykorzystanie podejścia intuicyjnego umożliwia przeanalizowanie } \\
\text { i przefiltrowanie znacznej ilości informacji. Dzięki podejściu } \\
\text { analitycznemu możliwe jest rozłożenie problemu decyzyjnego } \\
\text { na części i antycypowanie skutków decyzji jako całościa. }\end{array}$ \\
\hline $\begin{array}{l}\text { Umiejętności intuicyjnej } \\
\text { oceny }\end{array}$ & $\begin{array}{l}\text { Czynnikiem, który w znacznej mierze decyduje o powodzeniu } \\
\text { prowadzonej dziatalności, jest intuicja przedsiębiorcy. Nie } \\
\text { wszystko da się zmierzyć, skalkulować i przewidzieć. Do pewnego } \\
\text { etapu procesu decyzyjnego przedsiębiorca rozpatruje problem } \\
\text { decyzyjny racjonalnie i analitycznie, następnie istotną rolę odgrywa } \\
\text { intuicja. Ma ona szczególne znaczenie w sytuacji, w której istnieje } \\
\text { konieczność szybkiego podjęcia decyzji, występuje wiele możliwych } \\
\text { wariantów decyzji przy jednoczesnym braku wyraźnego kryterium } \\
\text { wyboru oraz w sytuacji unikatowej, bezprecedensowejb. }\end{array}$ \\
\hline $\begin{array}{l}\text { Umiejętność } \\
\text { rozwiązywania } \\
\text { problemów (gotowość } \\
\text { decyzyjna) }\end{array}$ & $\begin{array}{c}\text { Skutecznego przedsiębiorcę charakteryzuje samodzielność } \\
\text { w podejmowaniu decyzji oraz tzw. gotowość decyzyjna } \\
\text { - umiejętność podejmowania decyzji nawet w sytuacji braku } \\
\text { wystarczających informacjic. }\end{array}$ \\
\hline Kreatywność & $\begin{array}{l}\text { Skutecznego przedsiębiorcę określa się mianem inicjatora postępu } \\
\text { i rozwoju (osoba tamiąca stereotypy i czerpiąca radość z bycia } \\
\text { kreatywnym). Jest to osoba pomystowa, obdarzona wyobraźnią, } \\
\text { rozumiejąca znaczenie twórczego podejścia w kreowaniu rozwiązań } \\
\text { problemu decyzyjnego. Optymalna decyzja często wymaga } \\
\text { nieszablonowego podejścia i proponowania rozwiązań niebędących } \\
\text { kontynuacją wcześniejszych działań. }\end{array}$ \\
\hline Odporność psychiczna & $\begin{array}{l}\text { Przedsiębiorcę odznacza wysoki stopień akceptacji ryzyka } \\
\text { i zdolność do podejmowania ryzyka przy jednoczesnej umiejętności } \\
\text { oszacowania jego poziomu. W związku z tym skuteczny } \\
\text { przedsiębiorca powinien być człowiekiem odpornym psychicznie, } \\
\text { wytrwałym i nieustępliwym. }\end{array}$ \\
\hline Uważność & $\begin{array}{l}\text { Istotną cechą skutecznego przedsiębiorcy jest jego uważność, } \\
\text { określana mianem czujnej koncentracji. Oznacza ona zdolność } \\
\text { do identyfikowania szans i zagrożeń pojawiających się w otoczeniu. }\end{array}$ \\
\hline $\begin{array}{l}\text { Akceptacja i pewność } \\
\text { siebie }\end{array}$ & $\begin{array}{l}\text { Za charakterystyczne cechy skutecznego przedsiębiorcy uznaje się } \\
\text { wiarę we własne siły i możliwość realizacji danego przedsięwzięcia. } \\
\text { Osoby o wysokiej samoocenie nie ulegają presji otoczenia, } \\
\text { w związku z czym są w stanie podejmowá słuszne decyzjed. }\end{array}$ \\
\hline
\end{tabular}




\begin{tabular}{|l|l|}
\hline \multicolumn{1}{|c|}{$\begin{array}{c}\text { Pożądane cechy } \\
\text { współczesnego } \\
\text { przedsiębiorcy }\end{array}$} & \multicolumn{1}{c|}{ Opis cechy } \\
\hline $\begin{array}{l}\text { Wysoki poziom } \\
\text { umiejętności } \\
\text { społecznych (zwłaszcza } \\
\text { komunikacji) }\end{array}$ & $\begin{array}{l}\text { Jedną z cech skutecznego przedsiębiorcy jest zdolność } \\
\text { nawiązywania odpowiednich relacji biznesowych. Na zdolność } \\
\text { tę skadąą się takie umiejętności jak komunikacja, negocjowanie, } \\
\text { argumentowanie i zjednywanie sobie ludzi (zwłaszcza } \\
\text { interesariuszy) oraz przekonywanie ich do swoich planów. }\end{array}$ \\
\hline
\end{tabular}

a R.A. Baron, Cognitive mechanisms in entrepreneurship: Why and when entrepreneurs think differently than other people, „Journal of Business Venturing” 1998, vol. 13, no. 4, s. 275-294.

b K. Malewska, Intuicja w podejmowaniu decyzji kierowniczych, Wydawnictwo Uniwersytetu Ekonomicznego w Poznaniu, Poznań 2018, s. 102-103.

c A. Brzeziński, Przedsiębiorczość. Teoria i praktyka, Wydawnictwo Wydziału Zarządzania Politechniki Częstochowskiej, Częstochowa 2016, s. 683.

d F. Kapusta, Przedsiębiorczość. Teoria i praktyka, Wydawnictwo Forum Naukowe, Poznań 2006, s. 28.

Źródto: opracowanie własne.

Przyjmując założenie, zgodnie z którym podstawą tworzenia dynamicznych zdolności przedsiębiorstwa są dynamiczne zdolności jednostki ${ }^{46}$, zasadne wydaje się pytanie o to, które $\mathrm{z}$ wymienionych cech przedsiębiorcy są kluczowe dla kształtowania dynamicznych zdolności jednostki, a w konsekwencji dynamicznych zdolności przedsiębiorstwa. W literaturze zwraca się szczególną uwagę na fakt, iż dynamiczne zdolności przedsiębiorcy, a pośrednio także dynamiczne zdolności przedsiębiorstwa, w znacznym stopniu uzależnione są od jego zdolności kognitywnych ${ }^{47}$.

Zdolności kognitywne definiowane są jako zdolności przedsiębiorcy do skutecznej realizacji jednego lub większej liczby procesów umysłowych składających się na proces poznania ${ }^{48}$. Definicja ta zwraca uwagę na czynności oraz funkcje, które pełni poznanie. Wśród czynności tych wymienić można skupienie uwagi, postrzeganie czy rozwiązywanie problemów. Mimo że czynności te oddziałują na siebie, stanowią odrębne procesy pełniące odmienne funkcje ${ }^{49}$.

46 D.J. Teece, Explicating dynamic capabilities...

47 V. Barrales-Molina, J. Benitez-Amado, M.N. Perez-Arostegiu, Managerial perceptions of the competitive environment and dynamic capabilities generation, „Industrial Management \& Data System" 2010, vol. 110, no. 9, s. 1355-1384; G.P. Hodgkinson, M.P. Healy, Psychological foundations of dynamic capabilities: reflexion and reflection in strategic management, „Strategic Management Journal” 2011, vol. 32, no. 13, s. 1500-1516; J.P. Eggers, S. Kaplan, Cognition and capabilities...; C.H. Helfat, M.A. Peteraf, Managerial cognitive capabilities...; D. Mudalige, N.A. Ismail, M.A. Malek, Exploratory Study on Relationship between Entrepreneur Characteristic and Dynamic Capabilities in Export SMES, „Paradigm” 2016, vol. 20, no. 2, s. 113-130.

48 C.H. Helfat, M.A. Peteraf, Managerial cognitive capabilities..., s. 970.

49 E.E. Smith, S. M. Kosslyn, Cognitive Psychology: Mind and Brain, Pearson, Upper Adele River 2007. 
Spośród cech wymienionych w tabeli 1 szczególnie istotne, z punktu widzenia procesu tworzenia dynamicznych zdolności jednostki, wydają się wszystkie cechy związane z procesem poznania, czyli zdolności kognitywne jednostki, tj. percepcja, poznanie społeczne, wnioskowanie, umiejętność rozwiązywania problemów, uważność, umiejętność komunikacji.

Sugeruje się, że aby skutecznie kształtować swoje dynamiczne zdolności, przedsiębiorcy nie muszą odznaczać się wysokim poziomem wszystkich zdolności kognitywnych. W indywidualnych sytuacjach poszczególne rodzaje dynamicznych zdolności jednostki mogą mieć większe znaczenie od pozostałych. Przykładowo: jeżeli kluczową dynamiczną zdolnością przedsiębiorcy jest zdolność wyczuwania szans i zagrożeń, wówczas powinien on odznaczać się wysokim poziomem zdolności kognitywnych, takich jak percepcja i uważność ${ }^{5}$. Poprzez koncentrację na odpowiednich bodźcach przedsiębiorcy mogą skupić uwagę na „skanowaniu” wybranych obszarów otoczenia międzynarodowego, istotnych z punktu widzenia internacjonalizacji lub innych stawianych celów. Dobra percepcja i uważność ułatwiają przedsiębiorcom odkrywanie oraz kreowanie szans na rynkach międzynarodowych poprzez skupianie uwagi na odpowiednich informacjach będących podstawą tego działania (dostawcach, klientach, partnerach). W ten sposób kognitywne zdolności percepcji i uważności zapewniają podstawę dla dynamicznej zdolności jednostki, jaką jest wyczuwanie ${ }^{51}$.

W przypadku, w którym najistotniejszą dynamiczną zdolnością przedsiębiorcy jest zdolność wykorzystywania okazji, przedsiębiorcę powinien charakteryzować wysoki poziom umiejętności rozwiązywania problemów oraz wnioskowania ${ }^{52}$. Decyzje dotyczące wykorzystania okazji w otoczeniu międzynarodowym poprzez inwestycje strategiczne wymagają uzasadnienia i zdolności rozwiązywania problemów w celu opracowania opcji inwestycyjnych i oceny ich potencjału zysku. Zaprojektowanie skutecznego modelu biznesu, który umożliwi wykorzystanie okazji na rynkach międzynarodowych, wymaga dostosowania wielu elementów modelu i uwzględnienia dopasowania strategicznego oraz komplementarności działań 53 . Zdolność przedsiębiorców do rozwiązywania problemów stanowi o sukcesie tych działań. Natomiast zdolność wnioskowania sprzyja ostrożnemu rozważeniu alternatywnych opcji wykorzystania okazji i podjęciu najlepszych decyzji.

50 C.H. Helfat, M.A. Peteraf, Managerial cognitive capabilities...

51 M. Posner, M. Rothbart, Research on attention networks as a model for the integration of psychological science, „Annual Review of Psychology” 2007, vol. 58, s. 1-23.

52 C.H. Helfat, M.A. Peteraf, Managerial cognitive capabilities...

53 M.A. Peteraf, R. Reed, Managerial discretion and internal alignment under regulatory constraints and change, „Strategic Management Journal” 2007, vol. 28, no. 11, s. 1089-1112. 
Z kolei u podstaw dynamicznych zdolności jednostki związanych ze zdolnością rekonfiguracji leżą co najmniej dwie zdolności kognitywne jednostki, a mianowicie umiejętności komunikacji oraz poznania społecznego ${ }^{54}$. Umiejętność rekonfiguracji zasobów, kompetencji i procesów może w dużej mierze zależeć od zdolności przedsiębiorców do przekonania pracowników do podjęcia stosownych inicjatyw. Odpowiedni język oraz umiejętności komunikowania celów przyspieszają dostosowanie poszczególnych części organizacji do zmian. Styl komunikacji, sposób, w jaki przedsiębiorcy komunikują cele, a w szczególności wizję firmy, może inspirować pracowników, zachęcać do podejmowania nowych inicjatyw oraz napędzać ducha przedsiębiorczości ${ }^{55}$. Osiągnięcie dopasowania zasobów i procesów podczas zmieniających się i różnorodnych warunków otoczenia międzynarodowego wymaga działań kooperacyjnych wspieranych przez umiejętność komunikacji, ale także zdolność poznania społecznego. Dzięki zdolności poznania społecznego przedsiębiorcy mogą zrozumieć punkt widzenia swoich potencjalnych partnerów biznesowych, a tym samym zapewnić mechanizmy wpływu na ich zachowanie. Ten aspekt jest szczególnie istotny w działalności międzynarodowej, gdzie różnice kulturowe stanowią często barierę mentalną ograniczającą zaufanie i współpracę.

\section{Związek między cechami przedsiębiorcy a dynamicznymi zdolnościami przedsiębiorstwa w dziatalności międzynarodowej - propozycja modelu koncepcyjnego}

Bazując na analizie literatury przeprowadzonej we wcześniejszych częściach rozdziału, na rysunku 1 przedstawiono koncepcyjny model wpływu cech przedsiębiorcy na kształtowanie dynamicznych zdolności przedsiębiorstw, umożliwiających skuteczną działalność na rynkach międzynarodowych.

Zidentyfikowane trzy główne dynamiczne zdolności przedsiębiorstw to wyczuwanie szans i zagrożeń, wykorzystanie okazji oraz rekonfiguracja zasobów. Dynamiczne zdolności przedsiębiorstw wpływają na skuteczną działalność międzynarodową, rozumianą jako realizacja celów związanych z ekspansją na nowe rynki zagraniczne oraz dalsze prowadzenie działalności na tych rynkach. Przedsiębiorstwa prowadzące działalność na rynkach międzynarodowych zazwyczaj muszą sobie radzić

54 J.B. Barney, L.W. Busenitz, Differences between entrepreneurs and managers in large organizations: biases and heuristics in strategic decision-making, „Journal of Business Venturing” 1997, vol. 12, no. 1, s. 9-30.

55 M. Sajdak, Zwinność strategiczna..., s. 120. 
z większą różnorodnością i zmiennością otoczenia, a także ponosić wyższe ryzyko. W związku z tym można założyć, że w przypadku podejmowania takiej działalności znaczenie dynamicznych zdolności przedsiębiorstw jest większe niż w sytuacji ograniczenia aktywności biznesowej do jednego rynku lokalnego. Pierwsza z dynamicznych zdolności przedsiębiorstwa - wyczuwanie - pozwala identyfikować okazje sprzyjające międzynarodowemu rozwojowi, oszacować nadarzające się szanse, ale i ryzyko działalności na rynkach zagranicznych. Z kolei zdolność wykorzystania okazji wiąże się bezpośrednio z wiedzą sprzyjającą właściwemu wykorzystaniu okazji w działalności międzynarodowej i prowadzeniu takiej aktywności, umożliwiając z kolei ekspansję na rynkach zagranicznych. Ostatnia z omawianych dynamicznych zdolności przedsiębiorstwa, czyli rekonfiguracja, wiąże się z adaptacją do zmian pojawiających się w otoczeniu międzynarodowym oraz modyfikacją zasobów i procesów strategicznych poprzez organizacyjne uczenie się i innowacje.

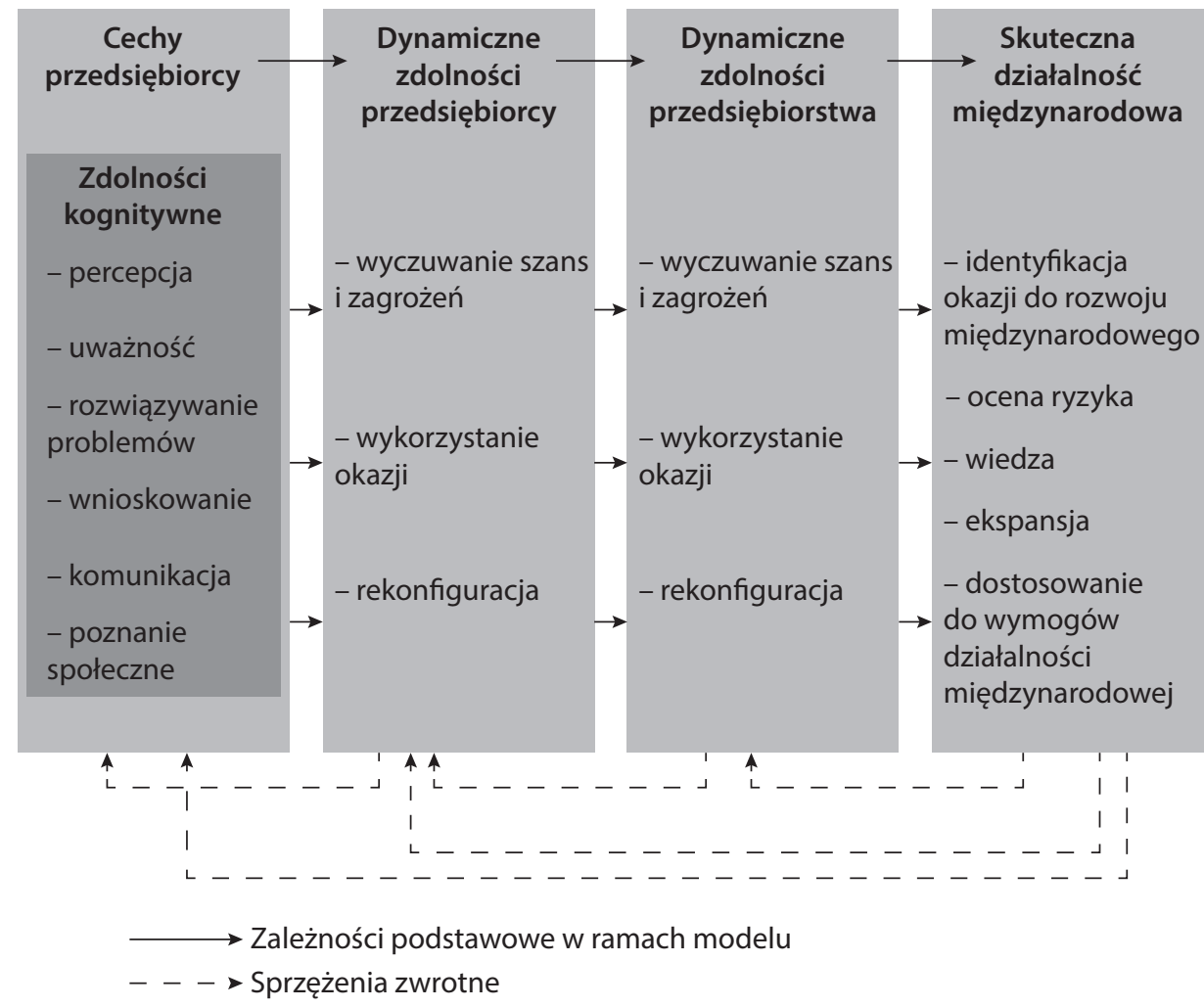

Rysunek 1 . Koncepcyjny model wpływu cech przedsiębiorcy na kształtowanie dynamicznych zdolności przedsiębiorstw, umożliwiających skuteczną dziatalność na rynkach międzynarodowych

Źródto: opracowanie własne. 
Dynamiczne zdolności przedsiębiorstwa są ściśle powiązane z dynamicznymi zdolnościami jednostki (właścicieli, menedżerów najwyższego szczebla). Można zauważyć, że dynamiczne zdolności jednostki odzwierciedlają znaczenie indywidualnych osób, natomiast dynamiczne zdolności przedsiębiorstw podkreślają znaczenie całej organizacji i wewnętrznych zależności w jej ramach (pomiędzy poszczególnymi pracownikami lub na przykład wykorzystywanymi zasobami) dla skutecznej działalności na rynkach zagranicznych.

Analiza literatury wykazała, że dla powstania dynamicznych zdolności przedsiębiorcy kluczowe są jego zdolności kognitywne. Stanowią one ważne cechy w ramach profilu przedsiębiorcy, które powinny być stale rozwijane i udoskonalane. Zdolności kognitywne percepcji i uważności przekładają się na dynamiczną zdolność przedsiębiorcy do wyczuwania szans i zagrożeń. Z kolei dla powstania dynamicznej zdolności wykorzystania okazji istotne są zdolności kognitywne, określane mianem umiejętności rozwiązywania problemów i wnioskowania. Natomiast za dynamiczną zdolność rekonfiguracji odpowiadają co najmniej dwie zdolności kognitywne jednostki, a mianowicie umiejętności komunikacji oraz poznania społecznego.

Zaproponowany model bazuje na założeniach Teece’a oraz Adnera i Helfat ${ }^{56}$, jednocześnie te założenia rozwijając. Po pierwsze, model wzbogacono, dodając szersze spojrzenie na cechy przedsiębiorcy. Po drugie, w modelu odniesiono się do wyników skutecznej działalności międzynarodowej. Powiązanie założeń Teece’a oraz Adnera i Helfat z działalnością międzynarodową pozwala wskazać aspekty tej działalności, które mogą ulec poprawie w przypadku koncentracji na rozwoju dynamicznych zdolności.

Należy zastrzec, że zaproponowany model ma pewne ograniczenia. W szczegółowym jego opisie skoncentrowano się na zależnościach liniowych i jednokierunkowych (od cech przedsiębiorcy po skuteczną działalność na rynkach międzynarodowych). Tymczasem możliwe są sprzężenia zwrotne, na przykład samo prowadzenie działalności międzynarodowej wpływa na rozwój cech przedsiębiorców i menedżerów odpowiedzialnych za prowadzenie takiej działalności.

Mimo że model bazuje na analizie literatury, należy uznać, że zaproponowany podział dynamicznych zdolności przedsiębiorstw i samych przedsiębiorców nie jest jedyny. Możliwe jest również zidentyfikowanie dodatkowych (poza osobą przedsiębiorcy) czynników wpływających na dynamiczne zdolności przedsiębiorstw - mogą to być na przykład czynniki otoczenia czy zasoby samego przedsiębiorstwa.

56 D.J. Teece, Explicating dynamic capabilities...; S.A. Adner, C.E. Helfat, Corporate effects... 


\section{Podsumowanie}

W rozdziale wykazano, że istnieje zależność między dynamicznymi zdolnościami jednostki (przedsiębiorcy, menedżera najwyższego szczebla) a dynamicznymi zdolnościami przedsiębiorstwa, gdzie dla powstania dynamicznych zdolności jednostki kluczowe są wybrane cechy przedsiębiorcy, stanowiące jego zdolności kognitywne. Dynamiczne zdolności przedsiębiorstwa są ważne dla działalności strategicznej i operacyjnej podejmowanej na rynkach międzynarodowych z powodu zmienności, różnorodności i ryzyka związanego z aktywnością zagraniczną prowadzoną w wielu krajach. Dlatego istotne jest uświadomienie przedsiębiorcom kluczowej roli wskazanych w modelu cech osobowości, będących jednocześnie zdolnościami kognitywnymi, którymi są percepcja, uważność, umiejętność rozwiązywania problemów, wnioskowanie, umiejętność komunikacji oraz poznanie społeczne.

Zaproponowany model koncepcyjny może mieć zastosowanie na przykład w badaniu okazji pojawiających się w procesie internacjonalizacji, dając odpowiedź na pytanie, co decyduje o tym, że jedne przedsiębiorstwa są bardziej skuteczne od innych w procesie identyfikowania, a przede wszystkim wykorzystywania i realizowania okazji sprzyjających prowadzeniu ekspansji na kolejne rynki zagraniczne. Model ma także zastosowanie praktyczne, wskazując osobom zarządzającym przedsiębiorstwami, że odmienny poziom dynamicznych zdolności (zarówno ich własnych, jak i całego przedsiębiorstwa) może różnicować efektywność w działalności międzynarodowej. Ważne jest przy tym wskazanie kompleksowości całego procesu, co wyraża się zależnościami i wzajemnym wpływem dynamicznych zdolności różnych osób zarządzających tym samym przedsiębiorstwem.

Zaproponowany model nie jest wolny od pewnych ograniczeń, które jednocześnie wyznaczają przyszłe kierunki badań. Omawiając model, skoncentrowano się przede wszystkim na zależnościach jednokierunkowych (poczynając od cech przedsiębiorcy), ich przełożeniu na dynamiczne zdolności jednostki i następnie dynamiczne zdolności przedsiębiorstwa wraz z podkreśleniem skuteczności dla działalności międzynarodowej. Tymczasem ważne jest podjęcie się identyfikacji zależności odwrotnych wraz z potencjalnymi sprzężeniami zwrotnymi. Przykładowo: dynamiczne zdolności wypracowane na poziomie przedsiębiorstwa poprzez środowisko pracy oddziałują na zarządzających tym przedsiębiorstwem menedżerów. Tym samym dynamiczne zdolności przedsiębiorstwa mogą wpływać na rozwój poszczególnych cech samych przedsiębiorców.

Ponadto w modelu skoncentrowano się na wpływie dynamicznych zdolności jednostki na dynamiczne zdolności przedsiębiorstwa. Tymczasem dla w pełni kompleksowego zobrazowania zależności konieczne jest zidentyfikowanie wpływu pozostałych (to jest niezwiązanych z osobą przedsiębiorcy) czynników 
przyczyniających się do rozwoju dynamicznych zdolności przedsiębiorstwa prowadzącego działalność na rynku międzynarodowym. Problematyka dynamicznych zdolności jest wciąż bardzo rozwojowa, stąd zasadne jest sugerowanie rozwoju badań w tym zakresie.

\section{Bibliografia}

Adner S.A., Helfat C.E., Corporate effects and dynamic managerial capabilities, „Strategic Management Journal" 2003, vol. 24, no. 10, s. 1011-1025.

Barney J.B., Busenitz L.W., Differences between entrepreneurs and managers in large organizations: biases and heuristics in strategic decision-making, „Journal of Business Venturing” 1997, vol. 12, no. 1, s. 9-30.

Baron R.A., Cognitive mechanisms in entrepreneurship: Why and when entrepreneurs think differently than other people, „Journal of Business Venturing” 1998, vol. 13, no. 4, s. 275-294.

Barrales-Molina V., Benitez-Amado J., Perez-Arostegiu M.N., Managerial perceptions of the competitive environment and dynamic capabilities generation, „Industrial Management \& Data System" 2010, vol. 110, no. 9, s. 1355-1384.

Beugelsdijk S., Liability of Foreignness and Location-Specific Advantages: Time, Space and Relative Advantage, „Advances in International Management” 2015, vol. 24, s. 181-210.

Brzeziński A., Przedsiębiorczość. Teoria i praktyka, Wydawnictwo Wydziału Zarządzania Politechniki Częstochowskiej, Częstochowa 2016.

Cao L., Dynamic capabilities in a turbulent market environment: empirical evidence from international retailers in China, „Journal of Strategic Marketing” 2011, vol. 19, no. 5, s. 455-469.

Cyfert S., Krzakiewicz K., The role of opportunity sensing and learning processes in shaping dynamic capabilities in Polish enterprises, „Management” 2016, vol. 20, no. 1, s. $277-291$.

Easterby-Smith M., Lyles M.A., Petaraf M.A., Dynamic Capabilities: Current Debates and Future Directions, „British Journal of Management” 2009, vol. 20, s. S1-S8.

Eggers J.P., Kaplan S., Cognition and capabilities: a multi-level perspective, „Academy of Management Annals" 2013, vol. 7, no. 1, s. 293-338.

Ellis P. D., Social ties and international entrepreneurship: Opportunities and constraints affecting firm internationalization, „Journal of International Business Studies” 2011, vol. 42, no. 1, s. 99-127.

Gorynia M., Strategie zagranicznej ekspansji przedsiębiorstw, Polskie Wydawnictwo Ekonomiczne, Warszawa 2007.

Gölgeci H.I., Assadinia S., Kuivalainen O., Larimo J., Emerging-market firms' dynamic capabilities and international performance: The moderating role of institutional development and distance, „International Business Review” 2019, vol. 28, no. 6, s. 1-13.

Gruber M., MacMillan I.C., Entrepreneurial behavior: A reconceptualization and extension based on identity theory, „Strategic Entrepreneurship Journal” 2017, vol. 11, no. 3, s. 271-286.

Hambrick D.C., Mason P.A., Upper echelons: The organization as a reflection of its top managers, „Academy Management Review” 1984, vol. 9, s. 195-206.

Helfat C.E., Peteraf M.A., Managerial cognitive capabilities and the microfundations of dynamic capabilities, „Strategic Management Journal” 2015, vol. 36, no. 6, s. 961-979.

Helfat C.E., Finkelstein S., Mitchell W., Peteraf M.A., Singh H., Teece D.J., Winter S.G., Dynamic Capabilities: Understanding Strategic Chance in Organization, Blackwell Publishing, Malden 2007. 
Hodgkinson G.P., Healy M.P., Psychological foundations of dynamic capabilities: reflexion and reflection in strategic management, „Strategic Management Journal” 2011, vol. 32, no. 13, s. $1500-1516$.

Kapusta F., Przedsiębiorczość. Teoria i praktyka, Wydawnictwo Forum Naukowe, Poznań 2006.

Knecht Z., Przedsiębiorczość i przedsiębiorca, Wyższa Szkoła Oficerska Wojsk Lądowych im. generała T. Kościuszki, Wrocław 2016.

Li M., Gao F., Why Nonaka highlights tacit knowledge: a critical review, „Journal of Knowledge Management" 2003, vol. 7, no. 4, s. 6-14.

Li Y., Chen H., Liu Y., Peng M.W., Managerial ties, organizational learning, and opportunity capture: a social capital perspective, „Asia Pacific Journal of Management” 2014, vol. 3, no. 1, s. 271-291.

Malewska K., Entrepreneurial profile and the level of individual entrepreneurship, [w:] C. Costa, M. Au-Yong-Oliveira, M.P. Castro Amorim (red.), Proceedings of the 13th European Conference on Innovation and Entrepreneurship ECIE 2018, Academic Conferences and Publishing International Ltd, Reading 2018, s. 443-449.

Malewska K., Intuicja w podejmowaniu decyzji kierowniczych, Wydawnictwo Uniwersytetu Ekonomicznego w Poznaniu, Poznań 2018.

Mitręga M., Dynamiczne zdolności - wzloty i upadki paradygmatu strategii, „Studia i Prace Wydziatu Nauk Ekonomicznych i Zarządzania Uniwersytetu Szczecińskiego" 2017, nr 48/2, s. 55-64.

Mitręga M., Henneberg S. C., Forkmann S., Capabilities in business relationships and networks: An introduction to the special issue, ,Industrial Marketing Management” 2018, vol. 74, s. 1-3.

Mitręga M., Forkmann S., Ramos C., Henneberg S. C., Networking capability in business relationship - concept and scale development, „Industrial Marketing Management” 2012, vol. 41, s. 739-751.

Mudalige D., Ismail N.A., Malek M.A., Exploratory Study on Relationship between Entrepreneur Characteristic and Dynamic Capabilities in Export SMES, „Paradigm” 2016, vol. 20, no. 2, s. $113-130$.

Najda-Janoszka M., Dynamic capability-based approach to value appropriation, Jagiellonian University Press, Cracow 2016.

Oleksyn T., Przedsiębiorczość jako kategoria złożona. Jak ją rozwijać?, „Problemy Zarządzania” 2012, t. 10, nr 1(36), s. 8-25.

Oviatt M.B., Shrader R.C., McDougall P.P., The internationalization of new ventures: A risk management model, [w:] M.A. Hitt, J.L.C. Cheng (red.), Theories of the Multinational Enterprise: Diversity. Complexity and Relevance, Emerald Group Publishing Limited, Amsterdam 2004, s. $165-185$.

Peteraf M.A., Reed R., Managerial discretion and internal alignment under regulatory constraints and change, „Strategic Management Journal” 2007, vol. 28, no. 11, s. 1089-1112.

Posner M., Rothbart M., Research on attention networks as a model for the integration of psychological science, „Annual Review of Psychology” 2007, vol. 58, s. 1-23.

Prange C., Verdier S., Dynamic capabilities, internationalization processes and performance, „Journal of World Business” 2011, vol. 46, no. 1, s. 126-133.

Ratajczak-Mrozek M., Network Embeddedness. Examining the Effect on Business Performance and Internationalization, Palgrave Macmillan, Cham 2017.

Sajdak M., Zwinność strategiczna przedsiębiorstw, Wydawnictwo Uniwersytetu Ekonomicznego w Poznaniu, Poznań 2019.

Schilke O., Hu S., Helfat C.E., Quo vadis, dynamic capabilities? A content-analytic review of the current state of knowledge and recommendation for future research, „Academy of Management Annals" 2018, vol. 12, no. 1, s. 390-439.

Shenkar O., Luo Y., International Business, Wiley, Chichester 2004.

Shippmann J.S., Ash R.A., Battista M., Carr L., Eyde L.D., Hesketh B., The practice of competency modeling, „Personnel Psychology” 2000, vol. 53, s. 703-740. 
Simon S., Houghton S. M., Aquino K., Cognitive biases, Risk Perception, and venture formation: How individuals decide to start companies, „Journal of Business Venturing” 2000, vol. 15, no. 2, s. 113-134.

Smith E.E., Kosslyn S. M., Cognitive Psychology: Mind and Brain, Pearson, Upper Adele River 2007. Spencer L.M., McClelland D.C., Spencer C., Competency Assessment Methods: History and State of the Art, Hay Mc-Ber Research Press, Boston 1994.

Teece D.J., Explicating dynamic capabilities: The nature and microfoundations of (sustainable) enterprise performance, „Strategic Management Journal” 2007, vol. 28, no. 13, s. 1319-1350.

Vahlne J.E., Johanson J., From internationalization to evolution: The Uppsala model at 40 years, „Journal of International Business Studies” 2017, vol. 48, no. 9, s. 1087-1102.

Vahlne J.E., Johanson J., The Uppsala internationalization process model revisited: From liability of foreignness to liability of outsidership, „Journal of International Business Studies” 2009, vol. 40, no. 9, s. 1411-1431.

Vijaya Sunder M., Ganesh L.S., Marathe R.R., Dynamic capabilities. A morphological analysis framework and agenda for future research, „European Business Review” 2018, vol. 31, no. 1, s. 25-63.

Winter S.G., Understanding dynamic capabilities, „Strategic Management Journal” 2003, vol. 24, s. 991-995.

Zahra S.A., George G., International entrepreneurship: The current status of the field and future research agenda, [w:] M.A. Hitt, R.D. Ireland, M. Camp, D. Sexton (red.), Strategic Entrepreneurship: Creating a New Mindset, Wiley-Blackwell, Oxford 2002, s. 253-288.

Zollo M., Winter S.G., Deliberate learning and the evolution of dynamic capabilities, „Organization Science" 2002, vol. 13, no. 3, s. 339-351.

\section{Streszczenie}

Coraz więcej przedsiębiorstw podejmuje się zmian strategicznych, decydując się na prowadzenie działalności międzynarodowej, związanej z obsługą zagranicznych klientów, współpracą międzynarodową lub wyłącznie pozyskiwaniem zagranicznych surowców. Jest to możliwe między innymi dzięki dynamicznie rozwijającym się zdolnościom, które stanowią odpowiedź na rosnącą dynamikę otoczenia. Egzemplifikują one możliwość dokonywania rekonfiguracji oraz zmiany w bazie zasobów i kompetencji w celu adaptowania się do warunków wysoce zmiennego otoczenia. W literaturze postuluje się, że cechy osobowości przedsiębiorcy (tak zwany profil przedsiębiorcy) mają wpływ na skuteczność podejmowania działań strategicznych i są ważne dla działalności międzynarodowej. Brakuje jednak badań łączących te perspektywy, tzn. osadzenia cech przedsiębiorcy w perspektywie dynamicznych zdolności, umożliwiających skuteczną działalność międzynarodową. Celem opracowania jest zidentyfikowanie wpływu cech przedsiębiorcy na kształtowanie dynamicznych zdolności przedsiębiorstw, umożliwiających skuteczną działalność na rynkach międzynarodowych. W rozdziale, na podstawie analizy literatury przedmiotu, zaproponowano model koncepcyjny zakładający istnienie zależności między cechami przedsiębiorcy, dynamicznymi zdolnościami jednostki, dynamicznymi zdolnościami całego przedsiębiorstwa oraz skutecznością działań strategicznych na rynkach międzynarodowych. W modelu wskazano, że cechy przedsiębiorcy przekładają się na dynamiczne zdolności przedsiębiorstwa, a w ich ramach ważną rolę odgrywają zdolności kognitywne jednostki.

Słowa kluczowe: przedsiębiorca, zdolności kognitywne, dynamiczne zdolności, działalność międzynarodowa, internacjonalizacja 


\section{Impact of entrepreneur's characteristics on shaping dynamic enterprise capabilities in international operations}

\section{Abstract}

More and more companies are undertaking strategic changes and deciding to conduct international activities related to servicing foreign customers, international cooperation or solely obtaining foreign raw materials. This is possible, among other things, thanks to dynamic capabilities that are a response to the growing dynamics of the business environment. Dynamic capabilities exemplify the possibility of reconfiguration and changes in the resources and competences base in order to adapt to highly dynamic environment. It is postulated in the literature that the entrepreneur's personality characteristics (the so-called entrepreneur's profile) have an impact on the effectiveness of companies' strategic actions and are important for their international activities. However, there is a lack of research combining these perspectives, that is combining the entrepreneurial characteristics in the perspective of dynamic capabilities enabling effective international activity. The aim of the article is to identify the impact of entrepreneurial characteristics on the process of shaping the dynamic capabilities of companies enabling these companies' effective business activities on international markets. The article, based on analysis of the literature of the subject, proposes a conceptual model assuming the existence of links between the entrepreneur's characteristics, the individual entrepreneurial dynamic capabilities, the company's dynamic capabilities and the effectiveness of strategic actions on international markets. The model indicates that the entrepreneur's characteristics translate into the dynamic capabilities of the enterprise, and within them an important role is played by the entrepreneurial cognitive capabilities.

Keywords: entrepreneur, cognitive capabilities, dynamic capabilities, international activity, internationalisation 